\title{
Differential Uptake of Endosulfan in the South American Toad Under Sublethal Exposure
}

\author{
Gabriela Svartz $^{1,3}$ - Damián Marino ${ }^{2,3}$ - Alicia Ronco ${ }^{2,3} \cdot$ Cristina S. Pérez Coll $^{1,3,4}$
}

Received: 10 March 2015/Accepted: 4 May 2015/Published online: 21 May 2015

(c) Springer Science+Business Media New York 2015

\begin{abstract}
Agroecosystems are usually polluted with a wide variety of contaminants with pesticides being very frequently detected. Endosulfan, an organochlorine pesticide, has been shown to cause both lethal and sublethal effects on aquatic organisms such as amphibians and especially on its early developmental stages. In this context, the aim of this study was to evaluate the uptake of environmentally relevant concentrations of endosulfan and its correlation with differential sensitivity in the early development stages of the common South American toad, Rhinella arenarum. Embryos and larvae were exposed to sublethal concentrations of endosulfan for several periods of exposures. According to the developmental stage at which they were exposed, the uptake rate was different. Bioconcentration factors (BCFs) for embryos significantly decreased with exposure time and concentration $(p<0.05)$ reaching a $\mathrm{BCF}$ of $\leq 1679$ for embryos at $96 \mathrm{~h}$ of exposure to $0.001 \mathrm{mg}$ endosulfan $\mathrm{L}^{-1}$. BCFs for larvae significantly increased with exposure time $(p<0.05)$ obtaining a
\end{abstract}

Cristina S. Pérez Coll

perezcoll@unsam.edu.ar; cris060957@yahoo.com.ar

1 Instituto de Investigación e Ingeniería Ambiental, Universidad Nacional de San Martín, Campus Miguelete, 25 de Mayo y Francia (C1650), San Martín, Buenos Aires, Argentina

2 Centro de Investigaciones del Medio Ambiente (CIMA), Departamento de Química, Facultad de Ciencias Exactas, Universidad Nacional de La Plata, Calle 47 y 115 (C1900), La Plata, Buenos Aires, Argentina

3 Consejo Nacional de Investigaciones Científicas y Técnicas (CONICET), Buenos Aires, Argentina

4 Escuela de Ciencia y Tecnología, Universidad Nacional de San Martín, Campus Miguelete, 25 de Mayo y Francia (C1650), San Martín, Buenos Aires, Argentina maximum of 40 at $504 \mathrm{~h}$. In our previous study, we reported that embryos were less sensitive to the effects of endosulfan than larvae, which is in line with the main tendency of embryos to bioconcentrate endosulfan as observed in this study.

Over recent decades, soybean crops have had a much larger overall expansion than any other crop, thus threatening natural ecosystems. In the last 50 years, soybean world production has substantially increased from 27 to 269 million tons in 2012. A total of $93 \%$ of the soybean world production came from just six countries; among them Argentina provides $21 \%$ of the total worldwide production. The area harvested for soybean in Argentina increased dramatically with production increasing from 8.5 million Ha in 1999-2000 to 19.5 million Ha in 2012-2013 (United States Department of Agriculture 2013). Soybean is attacked by a great diversity of defoliating caterpillars (Lepidoptera) during the growing season and increased populations of bugs during the fruiting stage (Hemiptera) (Di Marzio et al. 2010). The main insecticides used to control pests in these crops are endosulfan, cypermethrin, and chlorpyrifos. In addition, mixtures of these pesticides are often used simultaneously (Aragón et al. 1998).

Endosulfan is an organochlorine compound, the mechanism of which is mainly through overstimulation of the central nervous system by inhibiting calcium and magnesium ATPase (Paquette and Liem 1999). Endosulfan also interferes with the mechanism of the gammaaminobutyric acid (GABA) receptor, blocking the GABAgated chloride channel and decreasing neuronal inhibition, which leads to hyperexcitation of the central nervous system, convulsions, and death (Bloomquist 2003). Technicalgrade endosulfan is a mixture of alpha and beta isomers 
with the ratio of $7: 3$ being the most frequent chemical formulation (ATDSR 2000). After it is released into the environment, endosulfan, as other pesticides, is subject to transport and transformation processes that, in addition to environmental parameters and physicochemical properties, regulate their distribution and concentration in water, soil, sediments, and biota (Van der Oost et al. 2003). The high molecular-weight and the low water solubility of most organochlorine pesticides lead to their bioaccumulation in biota, mainly in fatty tissues, and consequent biomagnification through the food web (Newman and Unger 2003).

Endosulfan has been identified as a persistent organic pollutant (POP) due to its persistence, bioaccumulation, long-range transport, and adverse effects to human health and aquatic ecosystems (United Nations [UN] 2011). For these reasons, it has been classified as highly toxic by the majority of environmental protection agencies (Sutherland et al. 2004) and, according to the recommendation of the Scientific Committee, the UN Association in 2011 decided to promote the ban of the endosulfan worldwide use (UN 2011). However, despite regulations and restrictions, it is still largely used, particularly in some developing countries such as Argentina where it has been phased out since July 2013 (SENASA 2013).

Aquatic ecosystems integrate agricultural areas by providing water and drainage channels. As a consequence, these agroecosystems are continuously exposed to different types of toxic residues pesticides being relevant contaminants. The impact of endosulfan on Argentinean agroecosystems was significant in 2010 when 5.5 million liters of endosulfan were applied (CASAFE 2012) and residues frequently found in the environment in the range of 0.01-26 $\mathrm{g} \mathrm{L}^{-1}$ (Baudino et al. 2003; Dalvie et al. 2003; Wan et al. 2005b; Leong et al. 2007; Carriger and Rand 2008; Woudneh et al. 2009; Leadprathom et al. 2009; Etchegoyen 2014).

Amphibians, especially their embryo-larval development, are considered bioindicator species helping to detect changes in environmental quality both for their morphophysiological characteristics and their requirements of aquatic and terrestrial habitats, which thus make them more susceptible to physicochemical agents than other vertebrates. In light of changes in the environment (pollution, temperature variations, periods of drought, overgrazing, etc.) direct/indirect changes in survival and reproduction patterns can be seen. Bionda et al. (2013) reported that amphibians in altered Argentinean agroecosystems had lower egg and larval survival compared with organisms from noncultivated area with population projections less favorable leading to extinction in crop-dominated areas. Several laboratory studies reported adverse effects of endosulfan on amphibian embryo-larval development, i.e., lethality in various species at environmentally relevant concentrations (Jones et al. 2009; De Jong Westman et al.
2010), delay to complete metamorphosis (Brunelli et al. 2009), malformations of gills (Bernabó et al. 2008), failures in the endocrine system (Goulet and Hontela 2003), and neurotoxic effects (Agostini et al. 2009; Denoël et al. 2013; Svartz et al. 2014). However, most toxicity studies evaluate adverse effects under acute exposure condition only during certain periods of the life cycle. This is of concern when evaluating an eventual differential sensitivity to pesticides among different developmental stages. Although endosulfan toxicity was assessed through various studies, there is scarce information on the uptake of this compound in biota and less in amphibians.

Moreover, there is growing concern that amphibian populations are decreasing globally (Blaustein and Wake 1990; Alford and Richards 1999; Houlahan et al. 2000; Kiesecker et al. 2001), and several causes are believed to be involved, among them agriculture and aquaculture activities (International Union for Conservation of Nature 2014).

Toxicity bioassays represent useful tools to evaluate the risk of exposure of ecosystems to different physicochemical agents. AMPHITOX is a set of toxicity tests that employs embryos and larvae of $R$. arenarum providing information on mortality, malformations, delayed development, decreased growth, and behavioral abnormalities (Herkovits et al. 2002; Herkovits and Pérez-Coll 2003; Hutler Wolkowicz et al. 2013; Svartz et al. 2012). Moreover, AMPHITOX allows evaluation of the uptake of a chemical (Pérez-Coll et al. 1999; Herkovits and Pérez-Coll 2007; Pérez-Coll et al. 2008; Aronzon et al. 2014) as the assessment of stage-dependent susceptibility (Pérez-Coll and Herkovits 1990; Herkovits and Pérez-Coll 1993; Brodeur et al. 2009; Svartz et al. 2014) and expands the evaluation time, which allows obtaining acute, short-term chronic, and chronic toxicity results. In this context, the aim of this study was to evaluate, in a comparative way, endosulfan uptake in the embryonic and larval development of $R$. arenarum. In addition, we also sought to assess a correlation with the differential sensitivity we previously reported (Svartz et al. 2014) and the uptake of the pesticide under several periods of exposures of increasing time by means of the AMPHITOX test.

\section{Materials and Methods}

\section{$\boldsymbol{R}$. arenarum Embryos}

Three mating pairs of adult toads of $R$. arenarum, approximately 200-250 g, were obtained in Moreno (Buenos Aires province, Argentina). Toad care, breeding, embryo obtainment, and analysis were performed according to the methods described in the AMPHITOX protocols (Herkovits et al. 2002; Herkovits and Pérez-Coll 2003). Ovulation 
of females was induced by means of an intraperitoneal injection of a suspension of one homogenized toad pituitary gland in $1 \mathrm{~mL}$ of AMPHITOX solution (AS) plus $5000 \mathrm{IU}$ of human chorionic gonadotropin (hCG) per female preserved according to Pisanó (1956). The AS composition is (in $\mathrm{mg} \mathrm{L}^{-1}$ ) $\mathrm{Na}^{+} 14.75, \mathrm{Cl}^{-} 22.71, \mathrm{~K}^{+} 0.26$, $\mathrm{Ca}^{2+} 0.36$, and $\mathrm{HCO}_{3}{ }^{-}$1.45. Oocytes were fertilized in vitro using a testicular macerate homogenate suspended in AS resulting in a spermatozoid suspension of $10 \%$. The sperm viability was confirmed by observing the spermatozoid morphology and movements under an optical microscope. The eggs were inspected for quality and fertility and were considered acceptable if the fertility rate was $>75 \%$ and embryo survival at the neurula stage was $>70 \%$. The jelly coat was dissolved by immersing egg ribbons in a solution of $2 \%$ thioglycolic acid at $\mathrm{pH} 7.2$ containing $1.35 \mathrm{~mL}$ of saturated sodium hydroxide $(\mathrm{NaOH})$ solution in $100 \mathrm{~mL}$ of AS. This step was followed by a thorough wash of the embryos. Embryos were kept in AS and maintained at $20 \pm 2{ }^{\circ} \mathrm{C}$. The AS was replaced entirely every 3 days and monitored weekly to ensure that the $\mathrm{pH}$ was at acceptable levels $(7 \pm 0.5)$. Embryos were staged according to Del Conte and Sirlin (1951).

\section{Test Solutions}

Test solutions were performed using technical-grade endosulfan (PS81; Supelco, Sigma-Aldrich) with a purity of $99 \%$. A stock solution containing $10 \mathrm{mg}$ of endosulfan $\mathrm{L}^{-1}$ was prepared by dissolving endosulfan in analytical-grade acetone. The exposure concentrations were prepared by diluting the stock solution. Acetone concentration in test solutions was always $<1.1 \%$ to ensure no toxic effects from exposure to solvent (American Society for Testing and Materials 1993). Controls, both AS and acetone, were simultaneously maintained. Responses in both AS and acetone controls did not differ ( $p=0.05)$; therefore, the results were pooled for the analysis. The concentration of endosulfan was analyzed by high-performance liquid chromatography-electrospray ionization-mass spectrometry (negative mode), and the ions $\mathrm{m} / \mathrm{z}=405$ and $\mathrm{m} / \mathrm{z}=407$ were used for quantification and confirmation, respectively (Chusaksri et al. 2006). The solution was analyzed daily and was found to be stable over the exposure time. The error between nominal and measured concentration of the stock solution did not exceed $5 \%$.

\section{Experimental Design}

$R$. arenarum embryos were exposed to endosulfan solutions from early blastula stage (S.4, embryos, $4 \mathrm{~h}$ postfertilization) and complete operculum stage (S.25, early larvae, 7 days postfecundation) onward. For each experimental condition, 60 embryos or larvae were placed in triplicate (by each time period) in $20 \mathrm{~cm}$-diameter glass Petri dishes containing $200 \mathrm{~mL}$ of test solution, which were entirely replaced every $48 \mathrm{~h}$. Temperature between $20 \pm 2{ }^{\circ} \mathrm{C}$ and a 12:12-h light-to-dark photoperiod were maintained throughout the experiments, which lasted $504 \mathrm{~h}$. Test solutions ranged between 0.001 and 0.005 and between 0.0005 and $0.075 \mathrm{mg}$ of endosulfan $\mathrm{L}^{-1}$ for embryos and larvae, respectively. This concentration range was selected considering that the maximum exposure concentration was lower than the LC10 values obtained in our previous study (Svartz et al. 2014). Tadpoles were fed with balanced fish food TetraColor (Tetra): Eighteen granules were placed in each Petri dish every $48 \mathrm{~h}$. The uptake and wet weight were measured at three exposure times: 96, 240, and 504 h. At each time, 50 organisms were removed from each replicate, thoroughly washed with $200 \mathrm{~mL}$ of $\mathrm{AS}$, blotted dry on absorbent paper, and then weighed and stored at $-20{ }^{\circ} \mathrm{C}$ for analytical assessment.

\section{Analytical Method}

Whole organism tissue samples were used to determine endosulfan uptake in terms of BCFs expressed on a wetweight (ww) basis. Tissues were homogenized with sodium sulphate and then Soxhlet-extracted with hexane-and-acetone (1:1 ratio) mixture according method 3540C (United States Environmental Protection Agency (USEPA) 1996). The organic extracts were reduced to $0.5 \mathrm{ml}$ by roto evaporation followed by $\mathrm{N}_{2}$ flow. A cleanup step with fluorisil packed in a glass column using hexane and ethyl ether was applied according method 3620C (USEPA 2007). Endosulfan isomers ( $\alpha$ and $\beta$ ) were identified and quantified by gas chromatography (5890-II; Hewlett Packard)-mass spectrometry (MS; 5971; Hewlett Packard 5971). The analytical separation was performed with an HP-5 of $30 \mathrm{~m} \times 0.32-\mathrm{mm}$ column. Hydrogen was used as carrier at $0.8 \mathrm{ml} / \mathrm{min}$, split injection at $1: 50$ and $220{ }^{\circ} \mathrm{C}$, and oven ramp from 160 to $250{ }^{\circ} \mathrm{C}$ at $10{ }^{\circ} \mathrm{C} / \mathrm{min}$. Analyte identity was confirmed by $\mathrm{MS}$ using a single quadrupole operating in single-ion monitoring mode by monitoring ions $\mathrm{m} / \mathrm{z}=304,179$, and 37 , which had been previously characterized by scanning (between 70 and 550 umas). The recovery obtained was $98 \pm 3 \%$, equivalent for both isomers, and was determined using clean tadpoles.

\section{Data Analysis}

The deviation from the ratio isomers of $\alpha$-endosulfan to $\beta$ endosulfan in exposure solutions (7:3) was calculated indicating either differential metabolism of isomers or differential uptake by the organisms. In this study, uptake was defined as the accumulation of endosulfan in body tissues, and BCF (ww basis) were calculated as the concentration of 
the chemical in the organism $\left(\mu \mathrm{g} \mathrm{g}^{-1}\right) /$ exposure concentration $\left(\mathrm{mg} \mathrm{L}^{-1}\right)$. Two-way analysis of variance, repeated measures analysis, was used to assess significant differences of endosulfan uptake among embryos and larvae exposed to different conditions (exposure time and concentration). Multiple comparisons were performed using Bonferroni test. All data were expressed as mean $\pm \mathrm{SD}$, and statistical analyses were performed using GraphPad Prism version 5.0. The significance level was set at $p=0.05$.

\section{Results}

In Table 1, the levels of $\alpha$ - and $\beta$-endosulfan $\left(\mu \mathrm{g} \mathrm{g}^{-1}\right)$ and total endosulfan ( $\mu \mathrm{g} \mathrm{g}^{-1} \mathrm{ww}$ ) incorporated by embryos and larvae after different exposure times are listed. Control embryos and larvae had endosulfan concentrations lower than the detection limit (LOD; data not presented in the table), whereas all treatments showed detectable levels of both or one of the endosulfan isomers. In almost all treatments there were few deviations in the isomer ratio of $\alpha$-endosulfan to $\beta$-endosulfan, thus indicating either differential metabolism of isomers or differential uptake in $R$. arenarum. For larvae, the ratio was deviated to $\beta$-isomer at
$240 \mathrm{~h}$, and even at $504 \mathrm{~h}$ the $\alpha$-isomer levels were lower than the LOD.

The BCFs calculated for embryos and larvae are shown in Fig. 1. According to the developmental stage at which they were exposed, the uptake was different. BCFs for embryos decreased with exposure time and concentration $(p<0.05)$ reaching a $\mathrm{BCF} \leq 1679$ for embryos exposed at $96 \mathrm{~h}$ to the lowest concentration and a minimum of 1.30 at $504 \mathrm{~h}$ in those exposed to the highest concentration. In contrast, $\mathrm{BCF}$ for larvae increased with exposure time $(p<0.05)$ reaching a maximum near 40 at $504 \mathrm{~h}$ and a minimum of 6.24 at $240 \mathrm{~h}$. These results highlight that the uptake in embryos exposed at $240 \mathrm{~h}$ (reaching larval stage [S.25]) was greater $(p<0.05)$ than in larvae exposed from S.25 onward.

Comparative results for embryos and larvae exposed to 0.001 and $0.002 \mathrm{mg}$ of endosulfan $\mathrm{L}^{-1}$ at 240 and $504 \mathrm{~h}$ are shown in Fig. 2. Embryo BCFs were greater $(p<0.05)$ at the lower-exposure concentration for both exposure times being 1.60 and 2.35 times greater at 240 and $504 \mathrm{~h}$, respectively. Moreover, BCF values at $240 \mathrm{~h}$ for embryos were significantly greater than for larvae $(p<0.05)$, $\leq 11.45$ times; with this tendency reversed at $504 \mathrm{~h}$, larvae BCF had $\leq 3.09$ times greater concentrations than did embryos.

Table 1 Levels of $\alpha$ - and $\beta$-endosulfan (as $\mu \mathrm{g} / \mathrm{g}$ ) and total endosulfan (as $\mathrm{g} / \mathrm{g} \mathrm{ww})^{\mathrm{a}}$ incorporated on $R$. arenarum embryos and larvae after exposure to sublethal concentrations of technical endosulfan ${ }^{\mathrm{b}}$ during different times

\begin{tabular}{|c|c|c|c|c|c|c|c|}
\hline Stage & $\begin{array}{l}\text { Exposure } \\
\text { time (h) }\end{array}$ & $\begin{array}{l}\text { Exposure } \\
\text { concentrations (mg } \\
\left.\text { endosulfan } \mathrm{L}^{-1}\right)\end{array}$ & $\begin{array}{l}\alpha \text {-endosulfan } \\
\left(\mu \mathrm{g} \mathrm{g}^{-1}\right)\end{array}$ & $\begin{array}{l}\beta \text {-endosulfan } \\
\left(\mu \mathrm{g} \mathrm{g}^{-1}\right)\end{array}$ & $\begin{array}{l}\Sigma \text { endosulfan } \\
\left(\mu \mathrm{g} \mathrm{g}^{-1}\right)\end{array}$ & $\begin{array}{l}\text { Ratio of } \alpha \text { - } \\
\text { endosulfan to } \beta \text { - } \\
\text { endosulfan }\end{array}$ & $\mathrm{BCF}$ \\
\hline \multirow[t]{9}{*}{ Blastula } & \multirow[t]{3}{*}{96} & 0.001 & $1.246 \pm 0.254$ & $0.433 \pm 0.081$ & $1.679 \pm 0.319$ & $2.163 \pm 0.395$ & $1679.19 \pm 319.15$ \\
\hline & & 0.002 & $0.423 \pm 0.108$ & $0.143 \pm 0.028$ & $0.566 \pm 0.136$ & $2.935 \pm 0.178$ & $283.19 \pm 67.93$ \\
\hline & & 0.005 & $1.246 \pm 0.020$ & $0.420 \pm 0.036$ & $1.665 \pm 0.132$ & $2.964 \pm 0.421$ & $333.16 \pm 18.32$ \\
\hline & \multirow[t]{3}{*}{240} & 0.001 & $0.076 \pm 0.057$ & $0.038 \pm 0.019$ & $0.114 \pm 0.072$ & $1.879 \pm 0.784$ & $114.15 \pm 72.33$ \\
\hline & & 0.002 & $0.088 \pm 0.03$ & $0.055 \pm 0.002$ & $0.143 \pm 0.016$ & $1.608 \pm 0.255$ & $71.43 \pm 0.154$ \\
\hline & & 0.005 & $0.215 \pm 0.087$ & $0.106 \pm 0.040$ & $0.321 \pm 0.126$ & $2.012 \pm 0.273$ & $64.23 \pm 25.10$ \\
\hline & \multirow[t]{3}{*}{504} & 0.001 & $2.922 \pm 4.105$ & $0.012 \pm 0.008$ & $0.018 \pm 0.019$ & $1.619 \pm 0.158$ & $18.14 \pm 0.02$ \\
\hline & & 0.002 & $0.020 \pm 0.013$ & $0.005 \pm 0.002$ & $0.015 \pm 0.016$ & $4.307 \pm 0.145$ & $7.29 \pm 7.79$ \\
\hline & & 0.005 & $<\mathrm{LOD}$ & $0.007 \pm 0.004$ & $0.007 \pm 0.004$ & $<\mathrm{LOD}$ & $1.30 \pm 0.81$ \\
\hline \multirow{9}{*}{$\begin{array}{l}\text { Complete } \\
\text { operculum }\end{array}$} & \multirow[t]{3}{*}{96} & 0.01 & $0.060 \pm 0.038$ & $0.023 \pm 0.015$ & $0.083 \pm 0.052$ & $2.059 \pm 0.943$ & $8.27 \pm 5.19$ \\
\hline & & 0.05 & $0.400 \pm 0.102$ & $0.189 \pm 0.049$ & $0.589 \pm 0.143$ & $2.144 \pm 0.332$ & $11.76 \pm 2.85$ \\
\hline & & 0.075 & $0.435 \pm 0.050$ & $0.186 \pm 0.022$ & $0.621 \pm 0.018$ & $2.344 \pm 0.854$ & $8.28 \pm 0.10$ \\
\hline & \multirow[t]{3}{*}{240} & 0.0005 & $0.007 \pm 0.001$ & $0.008 \pm 0.005$ & $0.011 \pm 0.000$ & $0.611 \pm 0.002$ & $21.83 \pm 0.34$ \\
\hline & & 0.001 & $0.009 \pm 0.045$ & $0.012 \pm 0.004$ & $0.015 \pm 0.002$ & $1.2 \pm 0.001$ & $15.27 \pm 2.47$ \\
\hline & & 0.002 & $<\mathrm{LOD}$ & $0.012 \pm 0.009$ & $0.012 \pm 0.009$ & $<$ LOD & $6.24 \pm 4.39$ \\
\hline & \multirow[t]{3}{*}{504} & 0.0005 & $<\mathrm{LOD}$ & $0.018 \pm 0.003$ & $0.018 \pm 0.001$ & $<\mathrm{LOD}$ & $35.21 \pm 0.35$ \\
\hline & & 0.001 & $<\mathrm{LOD}$ & $0.041 \pm 0.023$ & $0.041 \pm 0.023$ & $<\mathrm{LOD}$ & $41.22 \pm 22.99$ \\
\hline & & 0.002 & $<\mathrm{LOD}$ & $0.045 \pm 0.023$ & $0.045 \pm 0.023$ & $<\mathrm{LOD}$ & $22.56 \pm 11.58$ \\
\hline
\end{tabular}

Data are expressed as mean \pm SD. Sample size $(n)=3$

$L O D$ lower than LOD

${ }^{\text {a }} \alpha$ - and $\beta$ - endosulfan

b $\alpha$ - to $\beta$-isomers $=7: 3$ ratio 

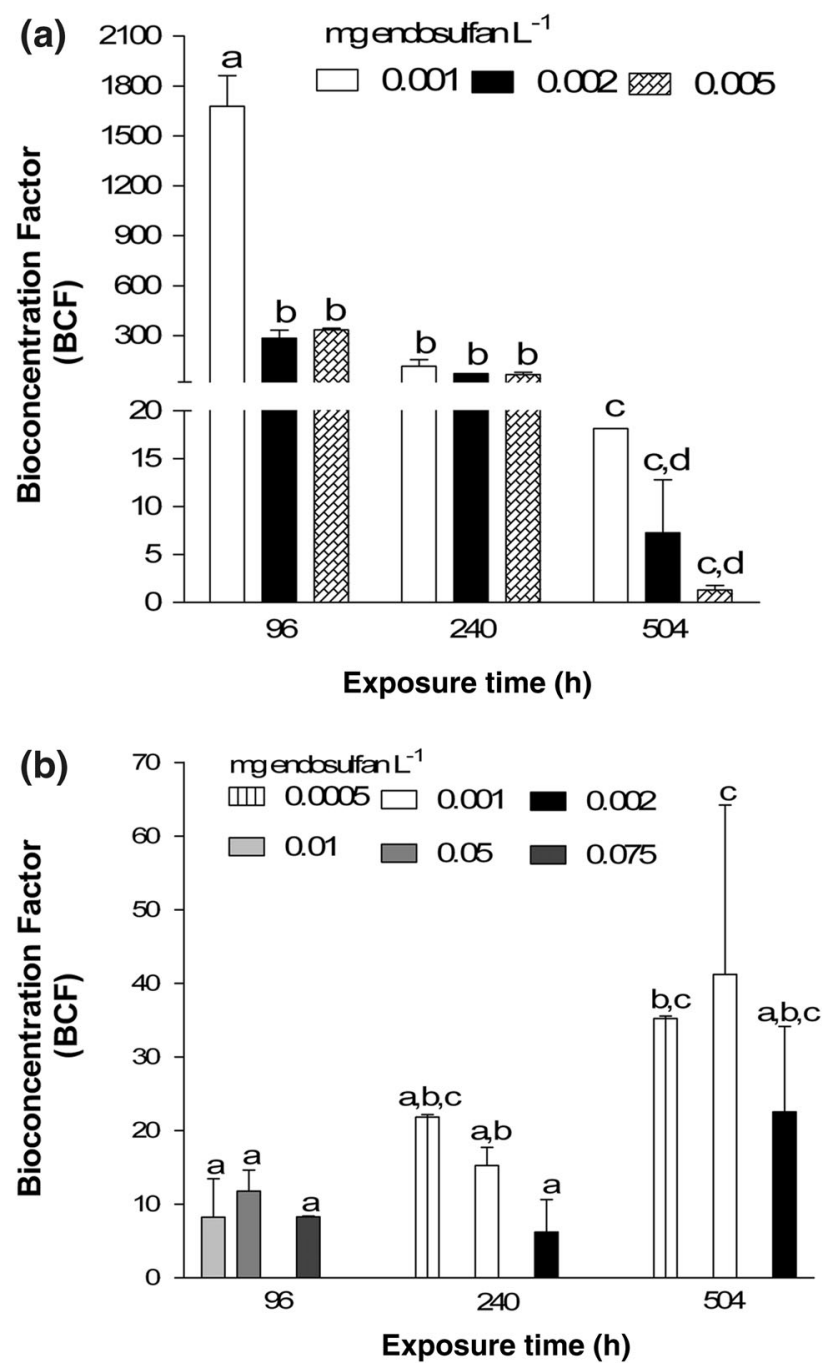

Fig. 1 BCFs of endosulfan for $R$. arenarum a embryos exposed from early blastula and $\mathbf{b}$ larvae exposed from complete operculum stages. Comparison of the BCF between different concentrations at each exposure time and at different exposure times. Different letters mean that values are statistically different at $p<0.05$

\section{Discussion}

Despite the fact that endosulfan is already banned worldwide, its high environmental persistence, bioconcentration, and biomagnification capacity through the trophic web, as well as its long range transport through the atmosphere, makes ecotoxicity assessment of this pesticide still of high relevance.

In a recent publication (Svartz et al. 2014), we reported the high toxicity of endosulfan to $R$. arenarum embryos and larvae with 504-h LC50 values of 0.03 (range $0.014-0.05$ ) and 0.01 (range $0.006-0.015$ ) $\mathrm{mg} \mathrm{L}^{-1}$, respectively. Moreover, we had characterized both lethal and sublethal effects of endosulfan on the embryo-larval development of $R$. arenarum, whereas in the present study we

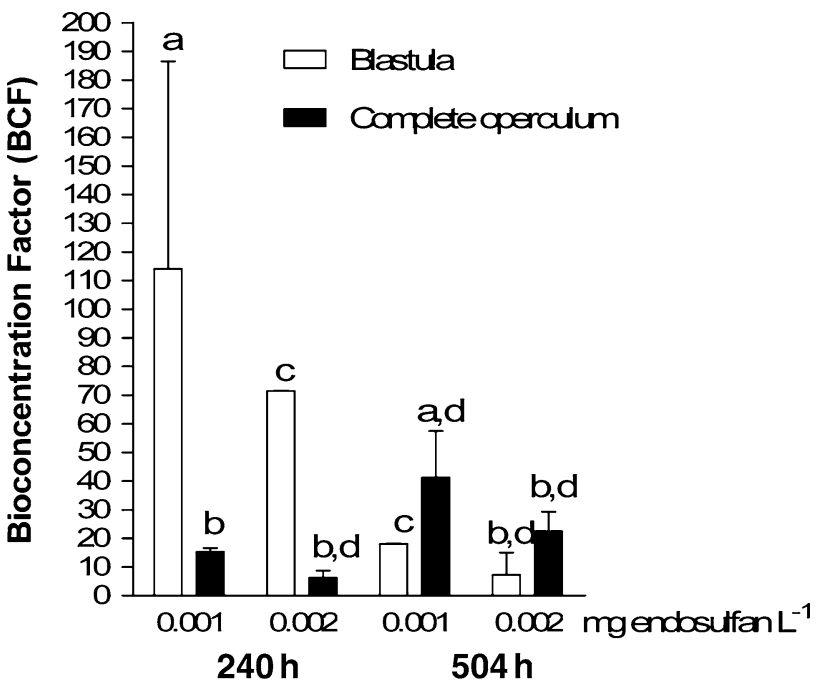

Fig. 2 Comparative BCFs at 240 and $504 \mathrm{~h}$ for embryos and larvae exposed to 0.001 and $0.002 \mathrm{mg}$ endosulfan $\mathrm{L}^{-1}$, respectively. Different letters means that values are statistically different at $p<0.05$

attempt to elucidate any correlation between developmental stage sensitivity and uptake of the pesticide. For this purpose, we evaluated the uptake in $R$. arenarum embryos and larvae exposed to sublethal endosulfan concentrations with the maximum exposure concentration being lower than the LC10 504-h value obtained in our previous study. The results highlight the differential uptake of endosulfan in the amphibian $R$. arenaum according to the developmental stage at which they were exposed. In this sense, embryonic uptake of the pesticide decreased with exposure time and concentration, whereas larval uptake increased with exposure time.

Generally, BCF is not considered to be significant unless the BCF exceeds 100 (USEPA 1991). The BCF values obtained for acute exposed embryos were $>100$ reaching up to 1679 for the lowest exposure concentration. The fact that the greater $\mathrm{BCF}$ values were related to the lower exposure concentrations was also observed for $R$. arenarum embryos exposed to nickel, an essential trace element that also caused, at lower concentrations, enhancement embryonic survival (Pérez-Coll et al. 2008). The maximum BCFs for endosulfan obtained in this study were greater than the maximum values reported for other amphibians as Bufo regularis adults $(\mathrm{BCF}=27)$ (Ezemonye and Tongo 2010) and were in the range of those reported for saltwater fish species in which BCFs ranged between 328 and 2755 (Schimmel et al. 1977; USEPA 1980; Toledo and Jonsson 1992).

$R$. arenarum larval period was the most sensitive developmental stage to endosulfan being at 96 and $168 \mathrm{~h}$ almost 26 times and 3 times more sensitive than embryos, respectively (Svartz et al. 2014). Moreover, embryos sensitivity significantly increased at $168 \mathrm{~h}$ coinciding with 
neuromuscular development, the main toxicity target of this pesticide (LC50 at $96 \mathrm{~h}=17.62$ [range 14.65-20.53] $\mathrm{mg}$ of endosulfan $\mathrm{L}^{-1}$ and LC50 at $240 \mathrm{~h}=0.81$ [range 0.26-1.25] mg of endosulfan $\mathrm{L}^{-1}$ ). It is interesting to note that this highest endosulfan resistance of embryos is in line with the great tendency to bioconcentrate the pesticide reported in this study reaching BCF values up to 1679 at $96 \mathrm{~h}$ of exposure. In contrast, larvae exposed from the beginning of their development showed a high sensitivity to the pesticide even with a low bioconcentration expressing lethal and sublethal effects (Svartz et al. 2014).

The enormous difference in the pesticide accumulation between embryos and larvae could be due to the high lipid content of the yolk of embryos. Thus, as previously stated, the lipophilic nature of endosulfan may allow it to easily partition from aqueous media into the lipid components of living cells (Rao and Lal 1987; Nagel and Loskill 1991). Furthermore, this differential accumulation between embryos and larvae was also observed for $R$. arenarum exposed to diazinon (Aronzon et al. 2014), although it was much less pronounced in the case of diazinon, in which embryo uptake could be $\leq 27$ times greater than larvae. In contrast, it was seen that both $R$. arenarum and Xenopus laevis exposed to cadmium at different developmental stages showed an increase in metal uptake at later developmental stages that was thought to be related to the gradual increase in the external surface of the larvae, the development of gills, and the possible transport of the contaminant across the membrane from the surface to inner organs (Herkovits and Pérez-Coll 1996; Herkovits et al. 1998).

The bioaccumulation of organic contaminants depends on the uptake and elimination rates of tissues/organs that are related to their abilities to metabolically transform the chemical (Nowak 1997). Once absorbed, a rapid transport of endosulfan throughout the body takes place. The pesticide may be transported by way of the lymphatic system or bloodstream and distributed to various body tissues including those of storage depots and sites of metabolism or biotransformation (Landis and Yu 2003). In this sense, one of the factors influencing the endosulfan decrease observed in embryos could be the metabolic transformation of endosulfan to its metabolites and excretion as was observed for other insecticides in fishes (Kanazawa 1975). The assessment in Atlantic salmon (Salmo salar) to dietary endosulfan exposure showed a significant induction of the CYP1A enzyme family at $710 \mu \mathrm{g} / \mathrm{kg}$ suggesting that CYP1A-mediated hydroxylation may be important for the metabolic transformation of endosulfan to the toxic metabolite, endosulfan sulfate (Glover et al. 2007). Moreover, the study on stereoselective metabolism of endosulfan by human liver microsomes and human CYP450 isoforms showed that the intrinsic clearances of endosulfan sulfate from $\beta$-endosulfan were 3.5-fold greater than those from $\alpha$-endosulfan suggesting that $\beta$-endosulfan would be cleared more rapidly than $\alpha$-endosulfan (Lee et al. 2006). This is opposite to that occurring in this study, in which ratios of $\alpha$-endosulfan to $\beta$-endosulfan were $<7: 3$, in both in embryos and larvae exposed to the pesticide, suggesting that $\alpha$-endosulfan would be metabolized more rapidly than $\beta$-endosulfan or could be an isomer differential uptake in the organisms. In addition, $\alpha$-endosulfan has been reported as the isomer most toxic in fishes and aquatic invertebrate organisms; endosulfan sulfate has a similar toxicity to the technical mixture ratio (7:3). The commercial formulations and $\beta$-endosulfan present the lowest toxicity (Wan et al. 2005a). Endosulfan as a POP could be retained on amphibian body tissue. When organisms are fed on by predators, the chemical concentrates from one trophic level to the next, thus leading to biomagnification causing severe ecological consequences (Newman and Unger 2003). Numerous articles have shown that aquatic organisms bioaccumulate lipophilic pollutants, notably organochlorines, and some of them showed a biomagnification though trophic transfer (Kidd et al. 1995; Rypel et al. 2007; Roche et al. 2009). Although endosulfan has already banned due to its persistence capability, it will still cause toxic effects at ecological levels.

Taking into account that endosulfan levels have been reported in the range from 0.1 to $26 \mu \mathrm{g} \mathrm{L}^{-1}$ in ground and surface water near agroecosystems (Baudino et al. 2003; Dalvie et al. 2003; Wan et al. 2005b; Leong et al. 2007; Carriger \& Rand 2008; Woudneh et al. 2009; Leadprathom et al. 2009), bioconcentration in embryos and larvae of $R$. arenarum could occur. Moreover, this phenomenon could be amplified by biomagnification and thus become a great concern not only as a risk to $R$. arenarum populations, which normally develop in those ecosystems, but also to trophically associated species. The results obtained in this study confirm the important potential uptake of $R$. arenarum embryo-larval development and are in line with the decisions to restrict and promote the ban of its worldwide use.

Acknowledgments Cristina Perez-Coll, Alicia Ronco, and Damián Marino are scientists at Consejo Nacional de Investigaciones Científicas y Técnicas (CONICET). Gabriela V. Svartz received a fellowship from CONICET. This study was supported by ANPCyT PICT 0891 and Universidad Nacional de San Martín. The authors thank Massone Institute Argentina for providing hCG hormones.

\section{References}

Agency for Toxic Substances and Disease Registry (2000) Toxicological profile for endosulfan. Public Health Service, United States Department of Health and Human Services, Atlanta

Agostini MG, Natale GS, Ronco AE (2009) Impact of endosulphan and cypermethrin mixture on amphibians under field use for biotech soya bean production. Int J Environ Health 3:379-389 
Alford RA, Richards SJ (1999) Global amphibian declines: a problem in applied ecology. Ann Rev Ecol Syst 30:133-165

American Society for Testing and Materials (1993) Standard guide for conducting the Frog Embryo Teratogenesis Assay-Xenopus (FETAX). Standards on aquatic toxicology and hazard evaluation. ASTM, Philadelphia

Aragón J, Molinari A, Lorenzatti S (1998) Manejo integrado de plagas de soja. In: Giorday L, Baigorri H (eds) El cultivo de soja en la Argentina. Instituto Nacional de Tecnología Agropecuaria, Marcos Juárez, pp 247-288

Aronzon CM, Marino DJ, Ronco AE, Pérez Coll CS (2014) Differential toxicity and uptake of diazinon on embryo-larval development of Rhinella arenarum. Chemosphere 100:50-56

Baudino OM, Suero EA, Augusto M, Jiménez ME, Flores N (2003) Monitoring organochlorine pesticides in surface and ground water in San Juan Argentina. J Chil Chem Soc 48:7-12

Bernabó I, Brunelli E, Berg C, Bonacci A, Tripepi S (2008) Endosulfan acute toxicity in Bufo bufo gills: ultrastructural changes and nitric oxide synthase localization. Aquat Toxicol $86: 447-456$

Bionda C, Lajmanovich R, Salas N, Martino A, di Tada I (2013) Demografía poblacional en Rhinella arenarum (Anura: Bufonidae) y Physalaemus biligonigerus (Anura: Leiuperidae) en agroecosistemas de la provincia de Córdoba, Argentina. Rev Biol Trop 61:1389-1400

Blaustein AR, Wake DB (1990) Declining amphibian populations: a global phenomenon? Trends Ecol Evol 5:203-204

Bloomquist JR (2003) Chloride channels as tools for developing selective insecticides. Arch Insect Biochem Physiol 54:145-156

Brodeur JC, Svartz G, Perez-Coll CS, Marino DJ, Herkovits J (2009) Comparative susceptibility to atrazine of three developmental stages of Rhinella arenarum and influence on metamorphosis: non-monotonous acceleration of the time to climax and delayed tail resorption. Aquat Toxicol 91:161-170

Brunelli E, Bernabò I, Berg C, Lundstedt-Enkel K, Bonacci A, Tripepi S (2009) Environmentally relevant concentrations of endosulfan impair development, metamorphosis and behaviour in Bufo bufo tadpoles. Aquat Toxicol 91:135-142

Cámara Argentina de Sanidad Agropecuaria y Fertilizantes (2012) Mercado argentino de productos fitosanitarios 2012. http://www. casafe.org/pdf/estadisticas/Informe\%20Mercado\%20Fitosanitar ios\%202010.pdf. Accessed 10 Mar 2015

Carriger JF, Rand GM (2008) Aquatic risk assessment of pesticides in surface waters in and adjacent to the Everglades and Biscayne National Parks: I. Hazard assessment and problem formulation. Ecotoxicology 17:660-679

Chusaksri S, Sutthivaiyakit S, Sutthivaiyakit P (2006) Confirmatory determination of organochlorine pesticides in surface waters using LC/APCI/tandem mass spectrometry open diamond. Anal Bioanal Chem 384:1236-1245

Dalvie MA, Cairncross E, Solomon A, London L (2003) Contamination of rural surface and groundwater by endosulfan in farming areas of the Western Cape, South Africa. Environ Health 2:1. www.ehjournal.net/content/2/1/1. Accessed 10 Mar 2015

De Jong Westman A, Elliott J, Cheng K, van Aggelen G, Bishop CA (2010) Effects of environmentally relevant concentrations of endosulfan, azinphosmethyl, and diazinon on Great Basin spadefoot (Spea intermontana) and Pacific treefrog (Pseudacris regilla). Environ Toxicol Chem 29:1604-1612

Del Conte E, Sirlin L (1951) The first stages of Bufo arenarum development. Acta Zool Lilloana 12:495-499

Denoël M, Libon S, Kestemont P, Brasseur C, Focant JF, De Pauw E (2013) Effects of a sublethal pesticide exposure on locomotor behavior: a video-tracking analysis in larval amphibians. Chemosphere 90:945-951
Di Marzio WD, Sáenz ME, Alberdi JL, Fortunato N, Cappello V, Montivero C et al (2010) Environmental impact of insecticides applied on biotech soybean crops in relation to the distance from aquatic ecosystems. Environ Toxicol Chem 29:1907-1917

Etchegoyen A (2014) Distribución de plaguicidas en aguas y sedimentos de fondo, en los principales afluentes de la cuenca del Paraguay-Paraná. Graduate Thesis, National University of La Plata, La Plata, Argentina

Ezemonye L, Tongo I (2010) Acute toxic effects of endosulfan and diazinon pesticides on adult amphibians (Bufo regularis). J Environ Chem Ecotoxicol 2:73-78

Glover CN, Petri D, Tollefsen KE, Jørum N, Handy RD, Berntssen MH (2007) Assessing the sensitivity of Atlantic salmon (Salmo salar) to dietary endosulfan exposure using tissue biochemistry and histology. Aquat Toxicol 84:346-355

Goulet BN, Hontela A (2003) Toxicity of cadmium, endosulfan, and atrazine in adrenal steroidogenic cells of two amphibian species, Xenopus laevis and Rana catesbeiana. Environ Toxicol Chem 22:2106-2113

Herkovits J, Pérez-Coll CS (1993) Stage-dependent susceptibility to cadmium on Bufo arenarum embryos. Bull Environ Contam Toxicol 50:608-611

Herkovits J, Pérez-Coll CS (1996) Stage-dependent uptake of cadmium by Bufo arenarum embryos. Bull Environ Contam Toxicol 56:663-669

Herkovits J, Pérez-Coll CS (2003) AMPHITOX: a customized set of toxicity tests employing amphibian embryos. In: Linder GL, Krest S, Sparling D, Little EE (eds) Multiple stressor effects in relation to declining amphibian populations. STP 1443. ATSM International, Philadelphia, pp 46-60

Herkovits J, Pérez-Coll CS (2007) Acclimation to low level exposure of copper in Bufo arenarum embryos. Int J Environ Res Public Health 4:166-172

Herkovits J, Cardellini P, Pavanati C, Pérez-Coll CS (1998) Cadmium uptake and bioaccumulation in Xenopus laevis embryos at different developmental stages. Ecotoxicol Environ Saf 39: $21-26$

Herkovits J, Pérez-Coll CS, Herkovits FD (2002) Ecotoxicological studies of environmental samples from Buenos Aires area using a standardized amphibian embryo toxicity test (AMPHITOX). Environ Pollut 116:177-183

Houlahan JE, Findlay CS, Schmidt BR, Meyer AH, Kuzmin SL (2000) Quantitative evidence for global amphibian population declines. Nature 404:752-755

Hutler Wolkowicz IR, Aronzon CM, Pérez Coll CS (2013) Lethal and sublethal toxicity of the industrial chemical epichlorohydrin on Rhinella arenarum (Anura, Bufonidae) embryos and larvae. J Hazard Mater 263:784-791

International Union for Conservation of Nature (2014) Red list of threatened species. www.iucnredlist.org. Accessed 10 Mar 2015

Jones DK, Hammond JI, Relyea RA (2009) Very highly toxic effects of endosulfan across nine species of tadpoles: lag effects and family-level sensitivity. Environ Toxicol Chem 28:1939-1945

Kanazawa J (1975) Uptake and excretion of organophosphorus and carbamate insecticides by fresh water fish, motsugo, Pseudorasbora parva. Bull Environ Contam Toxicol 14:346-352

Kidd KA, Schindler DW, Hesslein RH, Muir DCG (1995) Correlation between stable nitrogen isotope ratios and concentrations of organochlorines in biota from a freshwater food web. Sci Total Environ 161:381-390

Kiesecker JM, Blaustein AR, Belden LK (2001) Complex causes of amphibian population declines. Nature 410:681-684

Landis WG, Yu MH (2003) Introduction to environmental toxicology: impacts of chemicals upon ecological systems, 3rd edn. CRC Press, Boca Raton 
Leadprathom N, Parkpian P, Satayavivad J, Delaune RD, Jugsujinda A (2009) Transport and deposition of organochlorine pesticides from farmland to estuary under tropical regime and their potential risk to aquatic biota. J Environ Sci Health B 44:249-261

Lee HK, Moon JK, Chang CH, Choi H, Park HW, Park BS et al (2006) Stereoselective metabolism of endosulfan by human liver microsomes and human cytochrome P450 isoforms. Drug Metab Dispos 34:1090-1095

Leong KH, Tan LL, Mustafa AM (2007) Contamination levels of selected organochlorine and organophosphate pesticides in the Selangor River, Malaysia between 2002 and 2003. Chemosphere 66:1153-1159

Nagel R, Loskill R (1991) Bioaccumulation in aquatic systemscontributions to the assessment. $\mathrm{VCH}$, Verlagsgesellschaft, Weinheim

Newman MC, Unger MA (2003) Fundamentals of ecotoxicology, 2nd edn. Lewis Publishers, CRC Press, Boca Raton

Nowak BF (1997) Biological significance of xenobiotic residues in fish. Toxicol Ecotoxicol News 4:148-154

Paquette NC, Liem DS (1999) Endosulfan 079401: toxicology chapter for the reregistration eligibility document, CAS 115-29-7. Reregistration Branch II, Health Effects Division (7509C), Office of Pesticide Programs, OPPTS, USEPA

Pérez-Coll CS, Herkovits J (1990) Stage dependent susceptibility to lead in Bufo arenarum embryos. Environ Pollut 63:239-245

Pérez-Coll CS, Herkovits J, Fridman O, Daniel P, D́Eramo JL (1999) Metallothionein induction and cadmium uptake in Bufo arenarum embryos following an acclimation protocol. Environ Pollut 106:443-448

Pérez-Coll CS, Sztrum AA, Herkovits J (2008) Nickel tissue residue as a biomarker of sub-toxic exposure and susceptibility in amphibian embryos. Chemosphere 74:78-83

Pisanó A (1956) Efficienza funzionale e structura dell' ipofisi di anfibio. Arch Zool Ital 42:221-227

Rao N, Lal R (1987) Uptake and metabolism of insecticides by bluegreen algae Anabaena and Aulosira fertilissima. Microbiol Lett 36:143-147

Roche H, Vollaire Y, Persic A, Buet A, Oliveira-Ribeiro C, Coulet E et al (2009) Organochlorines in the Vaccarès Lagoon trophic web (Biosphere Reserve of Camargue, France). Environ Pollut 157:2493-2506

Rypel AL, Findlay RH, Mitchell JB, Bayne DR (2007) Variations in PCB concentrations between genders of six warmwater fish species in Lake Logan Martin, Alabama, USA. Chemosphere 68:1707-1715

Schimmel SC, Patrick JM, Wilson AJ (1977) Acute toxicity and bioconcentration of endosulfan in estuarine animals. In: Mayer FL, Hamelink JL (eds) Aquatic toxicology and hazard evaluation, 1st symposium. STP 634. ATSM, Philadelphia, pp 241-252

SENASA (2013) Resol 511/11 del Servicio Nacional de Sanidad y Calidad Agroalimentaria-Ministerio de Agricultura, Ganadería y
Pesca de la Nación. http://www.senasa.gov.ar/contenido.php?to= n\&in=1501\&ino=1501\&io=17737. Accessed 10 Mar 2015

Sutherland TD, Home I, Weir KM, Russell RJ, Oakeshott JG (2004) Toxicity and residues of endosulfan isomers. Rev Environ Contam Toxicol 183:99-113

Svartz GV, Herkovits J, Pérez-Coll CS (2012) Sublethal effects of atrazine on embryo-larval development of Rhinella arenarum (Anura: Bufonidae). Ecotoxicology 21:1251-1259

Svartz GV, Hutler Wolkowicz IR, Pérez Coll CS (2014) Toxicity of endosulfan on embryo-larval development of the South American toad Rhinella arenarum. Environ Toxicol Chem $33: 875-881$

Toledo MCF, Jonsson CM (1992) Bioaccumulation and elimination of endosulfan in zebra fish (Brachydanio rerio). Pestic Sci 36:207-211

United Nations (2011) Report of the conference of the parties to the Stockholm Convention on Persistent Organic Pollutants on the work of its fifth meeting, Geneva, 25-29 April 2011. http://chm. pops.int/. Accessed 10 Mar 2015

United States Department of Agriculture (2013) Foreign agricultural service, circular series. Oilseeds 13-01

United States Environmental Protection Agency (1980) Technical support document for water quality-based toxics control (EPA/ 505/2-90-001). USEPA, Washington, DC

United States Environmental Protection Agency (1991) Technical support document for water quality-based toxics control (EPA/ 505/2-90-001). USEPA, Washington, DC

United States Environmental Protection Agency (1996) Method 3540C. Soxhlet extraction. http://www.epa.gov/wastes/hazard/ testmethods/sw846/pdfs/3540c.pdf. Accessed 10 Mar 2015

United States Environmental Protection Agency (2007) Method 3620C. Florisil cleanup. http://www.epa.gov/wastes/hazard/test methods/sw846/pdfs/3620c.pdf. Accessed 10 Mar 2015

Van der Oost R, Beyer J, Vermeulen NP (2003) Fish bioaccumulation and biomarkers in environmental risk assessment: a review. Environ Toxicol Pharmacol 13:57-149

Wan MT, Kuo JN, Buday C, Schroeder G, Van Aggelen G, Pasternak J (2005a) Toxicity of $\alpha-, \beta-(\alpha+\beta)$-endosulfan and their formulated and degradation products to Daphnia magna, Hyalella azteca, Oncorrhynchus mykiss, Oncorrhyncus kisutch, and biological implications in streams. Environ Toxicol Chem 24:1146-1154

Wan MT, Kuo JN, Pasternak J (2005b) Residues of endosulfan and other selected organochlorine pesticides in farm areas of the Lower Fraser Valley, British Columbia, Canada. J Environ Qual 34:1186-1193

Woudneh MB, Ou Z, Sekela M, Tuominen T, Gledhill M (2009) Pesticide multiresidues in waters of the Lower Fraser Valley, British Columbia, Canada. Part I. Surface water. J Environ Qual 38:940-947 